\title{
Holocene vegetation and fire history of the Serra do Caparaó, SE Brazil
}

\author{
Nuno Veríssimo P,' Hugh DeForest Safford ${ }^{2}$ and \\ Hermann Behling ${ }^{\prime}$
}

\begin{abstract}
This study presents a recontruction of the Holocene vegetation and fire history of the Serra do Caparaó (Espírito Santo/Minas Gerais, SE Brazil) based on pollen and charcoal analysis from the $130 \mathrm{~cm}$ long core Primeiro Rancho I. Radiocarbon dates indicate a complete record of the Holocene (II,400 cal. $\mathrm{yr}$ BP to present). At the core site, high elevation grassland (campos de altitude) has been the dominant vegetation throughout the recorded period. In the early Holocene (I I,400 to 9000 cal. yr BP), a humid phase was followed by a drier one. Fires occurred continuously during the studied period but were more frequent in the early Holocene. Between 9000 and $2700 \mathrm{cal}$. yr BP, a gradual increase in the diversity and abundance of Atlantic montane forest taxa indicates an increase in humidity and/or rainfall; campos de altitude taxa still dominated but the montane forest taxon Symplocos was strongly present. Between 2700 and 1200 cal. yr BP, the arboreal Atlantic montane forest taxon Luehea became prominent but forest expansion halted and apparently reversed after 1200 cal. yr BP, possibly because of human activities. Simultaneously, campos de altitude expanded; abrupt variations in the pollen assemblages suggest environmental instability. Campos de altitude are a natural vegetation in Serra do Caparaó, but their present extent is likely influenced by anthropogenic activities, as several data suggest an increase of humidity after I $200 \mathrm{cal}$. yr BP, which should have caused a forest expansion. Reduction in human disturbance at higher elevations would thus probably result in succession to forest in some of the lower campos.
\end{abstract}

\section{Keywords}

Atlantic Forest, campos de altitude, Holocene vegetation, climate and fire history, pollen and charcoal analysis, SE Brazil, Serra do Caparaó

Received 28 January 20I I; revised mansucript accepted 6 December 201 I

\section{Introduction}

The Atlantic Forest of eastern South America stretches along the eastern coast of Brazil between $3^{\circ}$ and $30^{\circ} \mathrm{S}$, from Rio Grande do Norte and Ceará in the northeast to the southernmost states of Santa Catarina and Rio Grande do Sul, and further inland reaching southern Goiás, Paraguay, and the Province of Misiones in Argentina (Câmara, 2003; Gustavo et al., 2004; Hueck, 1966).

Physiographically, the Atlantic Forest is distinct from the more extensive Amazonian forests, as steep coastal mountains catch frontal systems as they arrive on the Brazilian east coast, and the orographically enhanced rainfall results in a dense 'escarpment forest' (Romariz, 1972) that is rarely more than 150 $\mathrm{km}$ in width. South of the State of Rio de Janeiro the Atlantic Forest escapes its mountainous limits and spreads $500 \mathrm{~km}$ beyond the Rio Paraná

Given its isolation from the forests of the Amazon Basin, the Atlantic Forest is a center of endemism for many taxonomic groups, especially primates and other mammals, amphibians, and plants (Galindo-Leal and Câmara, 2003; Garcia et al., 2004; Gustavo et al., 2004; Por, 1992). Lowland and montane forests along the Brazilian east coast are among the most species-rich on earth, but most lowland forests have been cut down and montane forests only remain in a loose patchwork of small National Parks and other conservation units (Dean, 1995). The Atlantic Forest biome is classified as one of the most biodiverse and endangered 'hotspots' on Earth (Backes and Irgang, 2004; Gustavo et al., 2004).

The Atlantic Forest sensu lato comprises different vegetations, whose wide spectrum of species and habitats can be categorized into five broad formations that are easily differentiated by their palynofloras: restinga (herbaceous, shrubland and open forest vegetation restricted to sandy substrates in coastal areas); lowland and montane evergreen forests (the Atlantic Forest sensu stricto); Araucaria forest (on some highlands in the southern Atlantic Forest); campos de altitude (primarily grassland and shrubland formations on the highest summits); and further inland, semideciduous tropical forest. Some areas of cerrado (the Brazilian savanna) are also found within the Atlantic Forest biome.

The climates encompassed by these formations vary substantially, with orography playing an important role. Lowland climates are primarily warm and humid (Nimer, 1979). Mean annual temperatures within the montane forest (c. $500 \mathrm{~m}$ to $2000 \mathrm{~m}$ elevation) range from about $20^{\circ} \mathrm{C}$ at lower elevations to $12^{\circ} \mathrm{C}$ at modern treeline (Safford, 1999a). Orographic lift of air masses increases annual precipitation levels in the montane zone, reaching $5000 \mathrm{~mm}$ in the Serra do Mar of southern Rio de Janeiro State, but averaging between 2000 and $3000 \mathrm{~mm}$ (Safford, 1999a). The rainy season (mean monthly precipitation $>50 \mathrm{~mm}$ ) lasts 9-12 months in most of the Atlantic Forest, with most locations experiencing a winter dry season of a few months (Nimer, 1979). Mean annual temperatures at the highest elevations in SE Brazil, in sites within the campos de altitude formation, can be as low as $8^{\circ}$, with freezing temperatures occurring on many winter nights (Safford, 1999b).

'Georg-August-University of Göttingen, Germany

${ }^{2}$ University of California, USA

\section{Corresponding author:}

Nuno Veríssimo P, Department of Palynology and Climate Dynamics, Albrecht-von-Haller Institute for Plant Sciences, Georg-AugustUniversity of Göttingen, Untere Karspüle 2, 37073 Göttingen, Germany.

Email: arkantor@hotmail.com 
SE Brazil is a mountainous region, and upper montane forests (c. 1500 to $2000 \mathrm{~m}$ ) and campos de altitude show an archipelagolike distribution on the higher mountain massifs. Mountains high enough to support campos de altitude ( $>1800-2000 \mathrm{~m})$ occur in the SE of Minas Gerais, in Espírito Santo, Rio de Janeiro, eastern São Paulo, and the coastal ranges of Paraná and Santa Catarina (Behling 2002; Martinelli, 1996; Safford, 1999a). The campos de altitude are tropical subalpine systems, and bear strong physiognomic, floristic, and environmental resemblances to tropical high elevation grass- and shrublands (páramos) in the equatorial Andes and central America (Safford, 1999a, 1999b, 2007). Of the plant species in the campos de altitude $10-15 \%$ are shared directly with the Andes, and more than $20 \%$ of taxa have Andean affinities; there are also surprisingly strong Andean connections within the fauna (Safford, 2007). The campos de altitude are dominated by grass, forb and shrub species, with scattered copses of dwarfed upper montane trees. About two-thirds of the campos de altitude flora is of tropical ancestry, $20-25 \%$ is of temperate (australantarctic and holarctic) ancestry and $10-15 \%$ is widely distributed (Safford, 2007); many species are local or habitat endemics (Martinelli, 1996; Safford, 1999a).

Like other humid tropical highlands, the campos de altitude support many areas of bog or fen habitat, where deep layers of peat and saturated, anoxic soil conditions preserve pollen records of past vegetation, climate, and disturbance. Previous palynological, biogeographic, floristic, and ecological studies in other highland sites in SE Brazil (e.g. Behling, 2002; Ruschi, 1950; Safford, 2007; Safford and Martinelli, 2000) have allowed better characterization of the high elevation vegetation formations within the Atlantic Forest and allow us to have a more accurate insight into its history, the relationships between its current diversity and extent and its past and present climates. Previous pertinent studies concerning the campos de altitude and/or the Atlantic montane forest include Araújo et al. (2005), Behling (1992, 1997, 2000, 2002), Behling et al. (2007), Behling and Safford (2010), Dean (1995), Garcia et al. (2004), Ledru (1993), Ledru et al. (1996), Power et al. (2008), Safford (1999a, 1999b, 1999c, 2001, 2007), Safford and Martinelli (2000), Salgado-Laboriau et al. (1998), and Schüler and Behling (2011a, 2011b).

The present paper extends work carried in SE Brazil to the Serra do Caparaó, a yet unstudied mountain range, and the highest, northernmost, and most continental of the campos de altitude sites. Like most of the campos de altitude, the Serra do Caparaó is located within a conservation unit (the Parque Nacional da Serra do Caparaó), but this has not protected the site from substantial human disturbance, in the form of logging, fire, livestock grazing, and - more recently - unmanaged recreation (Pádua and Coimbra Filho, 1979; Safford, 1999c). In this study we add to the geographic scope of the network of pollen core sites in the SE Brazilian highlands, and we use our data to make some inferences about the current extent and conservation status of the campos de altitude and the Atlantic montane forest, which might be useful for future conservation iniciatives in the Serra do Caparaó and ultimately within the Atlantic forest (sensu lato) biome.

\section{Study site}

The study site, Primeiro Rancho (20²4'50"S, 4149'34"W), is located in the NW of the Parque Nacional do Caparaó (Figure 1). The core used for this study (PR-I) was extracted from a bog surrounded by campos de altitude vegetation on a plateau slightly leaning towards south.

The Serra do Caparaó, in which the highest peak of eastern South America is found (Pico da Bandeira, $2890 \mathrm{~m}$ ), is largely underlain by high grade metamorphic bedrock, principally gneisses (Pádua and Coimbra Filho, 1979; Safford, 1999a). Soils are often highly organic and $\mathrm{pH}$ values are acidic to highly acidic (Safford, 1999c). The average annual temperature at the elevation of the core site $\left(2150 \mathrm{~m}\right.$ a.s.1.) is about $13^{\circ} \mathrm{C}$, wintertime minima fall below $-10^{\circ} \mathrm{C}$ and summertime mean maxima are $20-25^{\circ} \mathrm{C}$ (Safford, 1999c). Average annual precipitation varies between 1000 and $1500 \mathrm{~mm} / \mathrm{yr}$ and occurs mainly from October to April.

The Serra do Caparaó is home to more than 400 plant species belonging to 100 families (Leoni, 1997; Ruschi, 1950; Safford, unpublished data, 2010). The vegetation has been strongly altered and secondary formations with Alchornea, Cabralea, Cecropia, Drimys, Eugenia, Guarea, Inga, Machaerium, Nectandra, Ocotea, Piptadenia, Tecoma, Tibouchina and Vochysia are common (Pádua and Coimbra Filho, 1979). Below 2000 m elevation the natural dominant vegetation is evergreen and semi-deciduous montane forest. Above $2000 \mathrm{~m}$, the forest gives way to campos de altitude with Poaceae, Bromeliaceae, Ericaceae, Melastomataceae, Myrtaceae and Orchidaceae as the most important families (Brade, 1942). Patches of forest restricted mostly to rocky or south-facing sites of difficult access (Aguiar et al., 2003) above the current treeline suggest that the current extent of campos de altitude in the Serra do Caparaó may be anthropogenically magnified. For example, before the creation of Caparaó National Park in 1961, trees were cut and fires seasonally set in the campos de altitude by local ranchers and charcoal merchants, and the campos were heavily grazed by cattle (Pádua and Coimbra Filho, 1979; Ruschi, 1950; Safford, 1999c). Safford (2007) also suggests that the dominance of short-stemmed, adventive grasses, characteristic of seasonally dry, disturbed sites at lower elevations, such as Andropogon, Aristida, Axonopus and Paspalum in the lower campos de altitude may be due to anthropogenic burning in what was originally montane forest.

\section{Material and methods}

The Primeiro Rancho core (PR-I) was collected at $2150 \mathrm{~m}$ a.s.l. in 1998 using a Russian corer and consists of a $130 \mathrm{~cm}$ long peat core. Each of the three sections was rolled into protective layers of aluminium and plastic film and stored in situ in split PVC tubes for transportation. The cores have been stored since then in a controlled environment $\left(+4^{\circ} \mathrm{C}\right)$.

Samples for radiocarbon dating were taken at 30, 60, 90 and $123 \mathrm{~cm}$ and sent to the Center for Accelerator Mass Spectrometry, Lawrence Livermore National Laboratory (Livermore CA, USA). The original values, in ${ }^{14} \mathrm{C}$ years, were calibrated using the freeware application Calib 6.0 (Calib 6.0. (1986-2005) http:// calib.qub.ac.uk/calib/calib.html (20 May 2010); see Table 2). The sedimentation rate (Figure 2) was extrapolated to the whole core assuming a linear rate between each depth of known age. The sedimentation rate between $123 \mathrm{~cm}$ and the bottom of the core $(130 \mathrm{~cm})$ was assumed to be the same as that of between 90 and $123 \mathrm{~cm}$.

Sixty-five subsamples for pollen and charcoal analysis were taken along the core every $2 \mathrm{~cm}$ (starting at $1 \mathrm{~cm}$ ). In order to calculate concentrations and influx rates, a tablet of exotic Lycopodium spores was added to each sample. Further treatments followed standard palynological proceadures (see Fægri and Iversen, 1989). Pollen grains, spores and charcoal remains were counted on pollen slides under a $400 \times$ magnification until a minimum of 300 pollen grains per sample. Spores of the fungus Gelasinospora were counted, since these spores usually only germinate after a fire event (Alexopolous et al., 1996; Jensen and Elverland, 2002), their presence thus being a fire indicator.

Identification was possible through reference material of the palynomorphs of the SE Brazilian flora and the Neotropical Pollen search tool (Bush and Weng, 2006). The data were processed with TGView (including TILIA and Tiliagraph). Charcoal remains were 


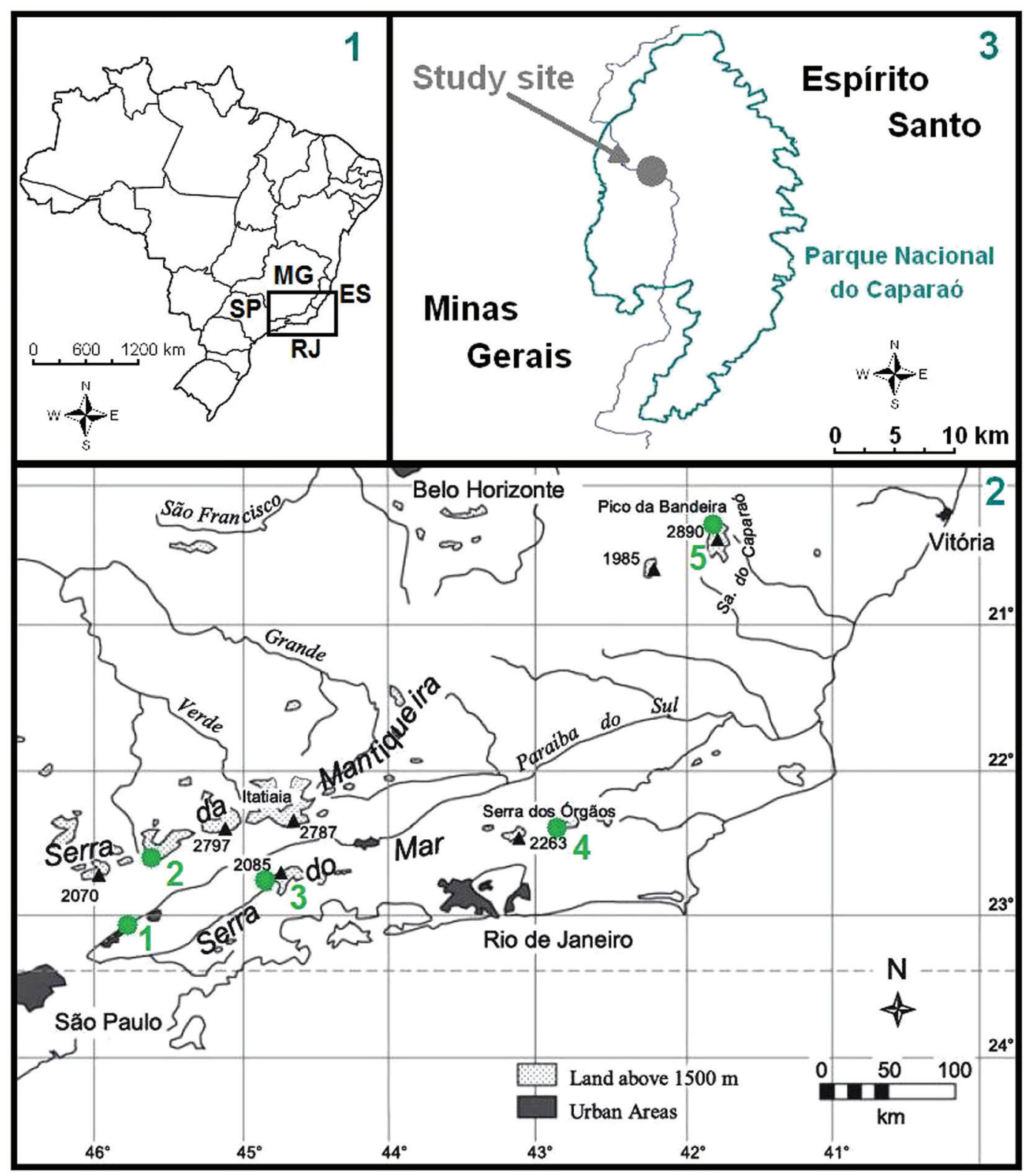

Figure I. Study site (Primeiro Rancho, $20^{\circ} 24^{\prime} 50^{\prime \prime} \mathrm{S}, 41^{\circ} 49^{\prime} 34^{\prime \prime W}$ ), within the Parque Nacional do Caparaó, Espírito Santo and Minas Gerais, SE Brazil. Other study sites mentioned in this paper: I: Garcia et al. (2004); 2: Morro de Itapeva (Behling, 1997); 3: Serra da Bocaina (Behling et al., 2007); 4: Serra dos Órgãos (Behling and Safford, 2010); 5: Serra do Caparaó (present paper).Abbreviations: BA: Bahia; ES: Espírito Santo; MG: Minas Gerais; RJ: Rio de Janeiro.

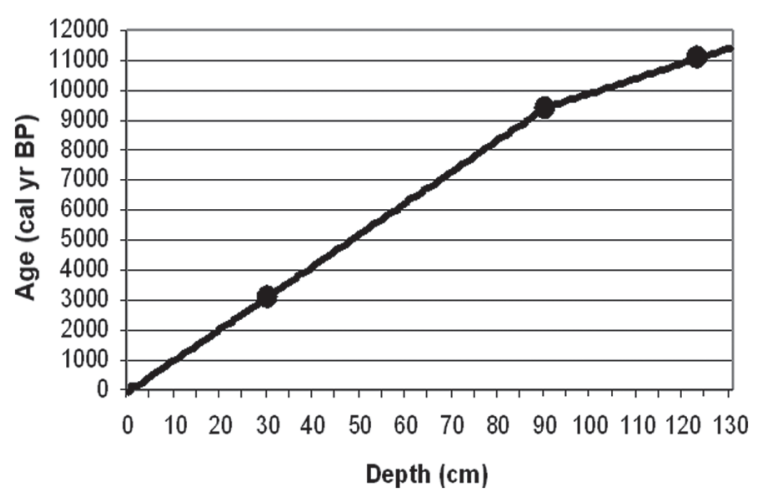

Figure 2. Sedimentation rate, depth against age (cal.yr BP). The highlighted depths correspond to the reference values $(30,90$ and $123 \mathrm{~cm}$ ) plus depth $=0 \mathrm{~cm}$. counted on the pollen slides and classified into two size classes: 5 to $75 \mu \mathrm{m}$ (small particles) and $>75 \mu \mathrm{m}$ (large particles).

Percentages of all taxa were calculated based on the pollen sum, which includes all pollen types assigned to the groups 'campos de altitude' (CA), 'Atlantic montane forest' (AMF; subdivided into 'upper montane forest' (UMF), '"general" montane forest' (GMF) and 'lower montane forest' (LMF)), 'exotics' and 'unknown \& indeterminate'. Each taxon was assigned to the group in which it is presently more common and/or ecologically relevant (see e.g. Marchant et al., 2002). The GMF subgroup includes all montane forest taxa which could not be assigned to just one of the other. The group 'Pteridophyta' is here used in its wider sense (as in Sitte et al., 1998) and includes both ferns and lycopods. Algae (not further identified) and Gelasinospora were left ungrouped.

The zonation of the pollen diagram (Figure 3 ) was established with regard to significant changes in the abundances of individual taxa and/or groups and to the CONISS analysis for stratigraphically 


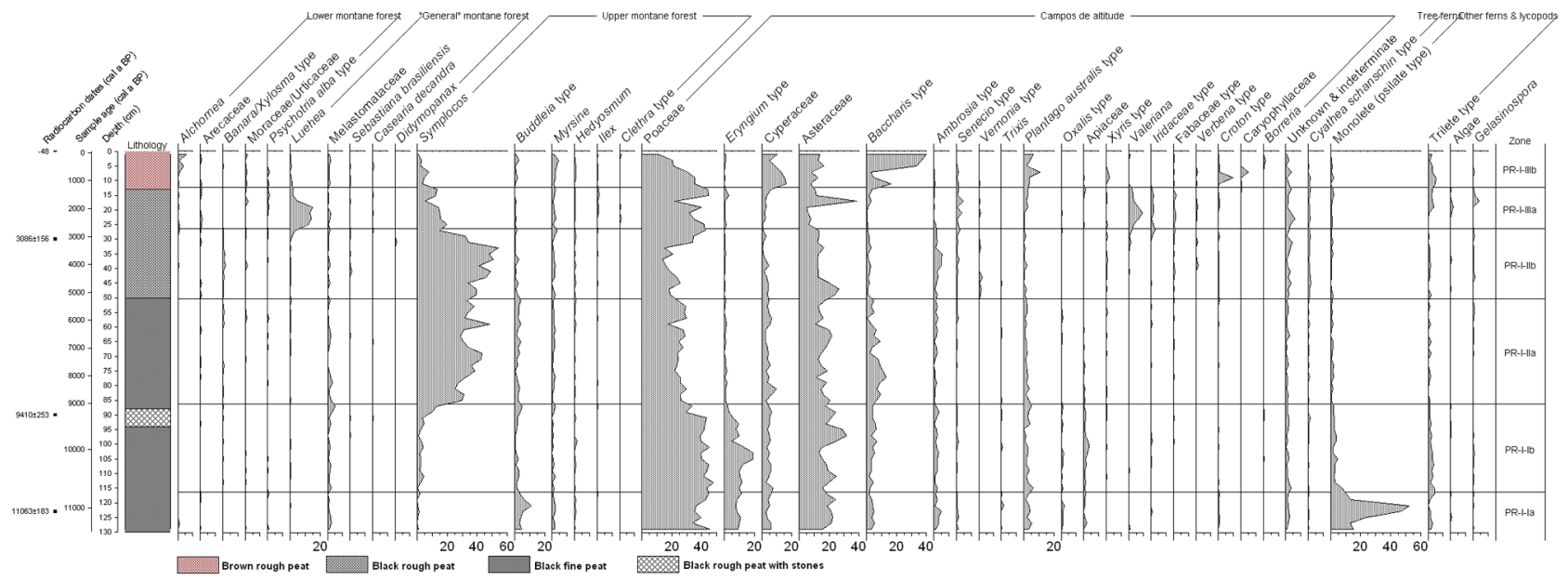

(a)

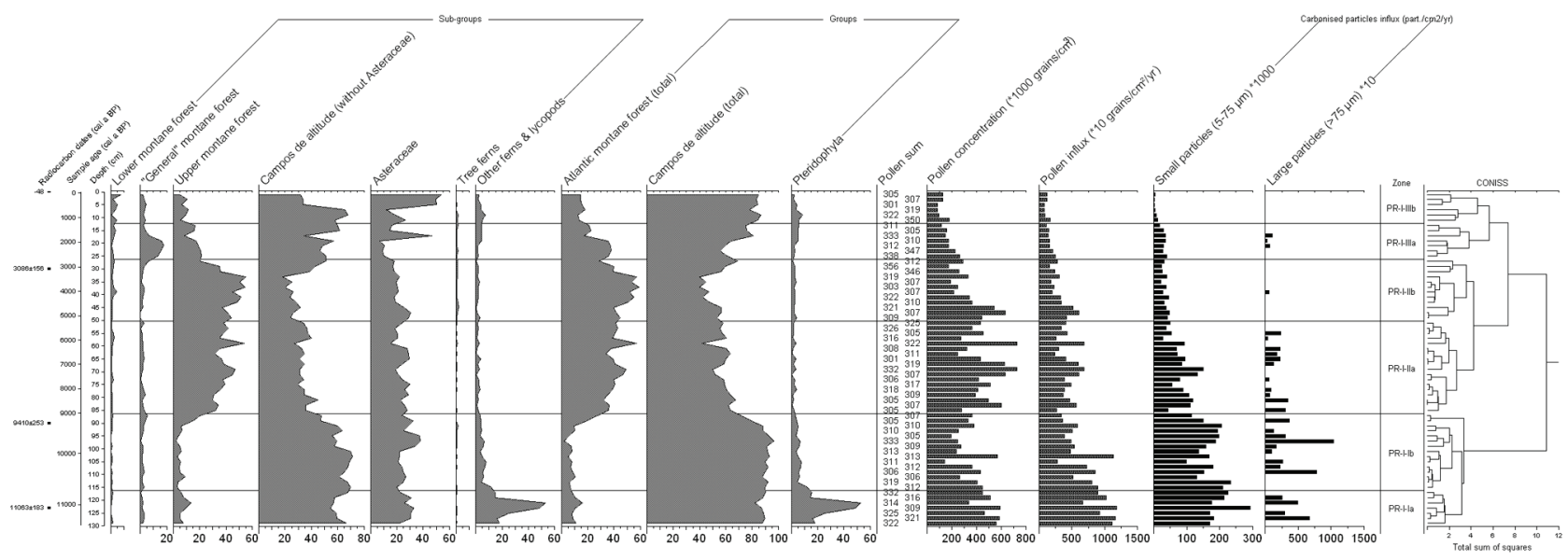

(b)

Figure 3. (a) Relative abundances of the individual taxa (rare types not shown). (b) Relative abundances of the AMF, CA, Pteridophyta and respective subgroups; pollen sum, pollen concentration, pollen influx; and influx of charcoal remains.

constrained samples (Grimm, 1987). Spores were not considered for this analysis.

\section{Results}

\section{Stratigraphy}

The $130 \mathrm{~cm}$ long PR-I core is mainly composed of an almost black, fine peat whose organic content is mostly decomposed. The sand content increases towards the bottom and roots are only present in the first $50 \mathrm{~cm}$. A more detailed description is given in Table 1 .

\section{Radiocarbon dates}

${ }^{14} \mathrm{C}$ ages were delivered for core depths 30,90 and $123 \mathrm{~cm}$ (Table 2); the only result obtained for the $60 \mathrm{~cm}$ sample was 'contaminated', numerical results are therefore unavailable. The sedimentation rate (see Figure 2) between $123 \mathrm{~cm}$ and the bottom of the core was assumed to be the same as between 90 and $123 \mathrm{~cm}(50.12 \mathrm{~cm} / \mathrm{yr})$; the extrapolated age at the bottom $(130 \mathrm{~cm})$ is thus $11,410 \mathrm{cal}$. yr BP.
Table I. Stratigraphy of the PR-I core.

\begin{tabular}{|c|c|}
\hline Depth $(\mathrm{cm})$ & Description \\
\hline $0-13$ & Brown peat, little decomposed; abundant small roots \\
\hline $13-50$ & $\begin{array}{l}\text { Black peat progressively finer towards the bottom; } \\
\text { more and larger roots }\end{array}$ \\
\hline $50-88$ & Black fine peat, strongly decomposed; no roots \\
\hline $88-94$ & $\begin{array}{l}\text { Black rough peat with some stones (up to } 10 \mathrm{~mm} \\
\text { diameter), strongly decomposed }\end{array}$ \\
\hline $94-130$ & $\begin{array}{l}\text { Black fine peat, strongly decomposed; sand content } \\
\text { increasing towards the bottom }\end{array}$ \\
\hline
\end{tabular}

\section{Description of the Serra do Caparaó pollen diagram}

In the 65 samples, a total of 83 pollen and spore taxa (plus algae) was found; 42 taxa are considered rare types (maximum abundance $<1 \%$; see Table 3 ) and are not shown in the pollen diagram (Figure 3). Six pollen zones were established in the PR-I core (Table 4).

Table 2. Results concerning the samples sent for radiocarbon dating (core depths 30,90 and $123 \mathrm{~cm}$ ).

\begin{tabular}{lclcc}
\hline Lab. number & $\begin{array}{l}\text { Depth } \\
(\mathrm{cm})\end{array}$ & $\begin{array}{l}{ }^{14} \mathrm{C} \text { age } \\
(\mathrm{yr} \mathrm{BP})\end{array}$ & $\begin{array}{l}\text { Calibrated age } \\
(\text { cal. yr BP })\end{array}$ & Modern fraction \\
\hline CAMS 56103 & 30 & $2980 \pm 40$ & $3086 \pm 156$ & 0.70 \\
CAMS 56104 & 90 & $8530 \pm 40$ & $9409 \pm 253$ & 0.35 \\
CAMS 56105 & 123 & $9800 \pm 50$ & $11063 \pm 183$ & 0.30 \\
\hline
\end{tabular}


Table 3. Taxa found in the PR-I core listed according to the vegetation they were assigned to. Rare types (maximum abundance $<1 \%$ ) are marked with an asterisk and are not shown in the pollen diagram (Figure 3).

\begin{tabular}{|c|c|}
\hline Lower mountain forest & Borreria \\
\hline Alchornea & Caryophyllaceae \\
\hline Arecaceae & Croton type \\
\hline Banara/Xylosma type & Cyperaceae \\
\hline Cecropia* & Ericaceae* \\
\hline Meliosma* & Eryngium type \\
\hline Moraceae/Urticaceae & Fabaceae type \\
\hline Psychotria alba type & Hydrocotyle type* \\
\hline 'General' mountain forest & Iridaceae type \\
\hline Casearia decandra & Jeronima* \\
\hline Cedrela fissilis type* & Lamiaceae* \\
\hline Celtis* & Mimosa (P4 type)* \\
\hline Chrysophyllum marginatum* & Moritzia dasiantha* \\
\hline Didymopanax & Ouratea type* \\
\hline Flacourtiaceae* & Oxalis type \\
\hline Fuchsia regia* & Plantago australis type \\
\hline Lithraea/Schinus type* & Plantago turficola type* \\
\hline Luehea & Poaceae \\
\hline Mabea type* & Polygala* \\
\hline Matayba* & Ranunculus* \\
\hline Melastomataceae & Salvia type* \\
\hline Myrtaceae* & Senecio type \\
\hline Prockia crucis type* & Spermacoce* \\
\hline Psychotria type* & Trixis \\
\hline Rhamnus type* & Valeriana \\
\hline Rhipsalis* & Verbena type \\
\hline Rubiaceae* & Vernonia type \\
\hline Sebastiana brasiliensis & Xyris type \\
\hline Struthanthus* & Exotic \\
\hline Styrax* & Alnus* \\
\hline Upper mountain forest & Unknown and Indeterminate \\
\hline Allophylus* & Tree ferns \\
\hline Buddleia type & Alsophila elegans type* \\
\hline Clethra type & Cyathea type* \\
\hline Hedyosmum & Cyathea schanschin type \\
\hline llex & Other ferns and lycopods \\
\hline Myrsine & Anemia* \\
\hline Oreopanax fulvum type* & Lycopodium* \\
\hline Prunus type* & Monolete (psilate) \\
\hline Symplocos & Monolete (verrucate)* \\
\hline Weinmannia type* & Selaginella* \\
\hline Campos de altitude & Trilete \\
\hline Amaranthaceae/Chenopodiaceae type* & Others \\
\hline Ambrosia type & Algae \\
\hline Apiaceae & Gelasinospora \\
\hline Asteraceae & \\
\hline
\end{tabular}

Table 4. Zonation of the PR-I core: corresponding depths, ages and number of samples.

\begin{tabular}{lccc}
\hline Pollen zone & Depth $(\mathrm{cm})$ & Age range (cal. yr BP) & Number of samples \\
\hline PR-I-IIIb & $0-12$ & $-48-1210$ & 6 \\
PR-IIIla & $12-26$ & $1210-2670$ & 7 \\
PR-I-IIb & $26-50$ & $2670-5190$ & 12 \\
PR-I-Ila & $50-86$ & $5190-8990$ & 18 \\
PR-I-Ib & $86-116$ & $8990-10,710$ & 15 \\
PR-I-la & $116-130$ & $10,710-11,410$ & 7 \\
\hline
\end{tabular}

Zone PR-I-Ia (I30-I I6 cm; I I,4 I0-10,7 I0 cal.yr BP; 7 samples). Within the AMF (10\%), the UMF is the most common subgroup $(8 \%)$ and Buddleia type the most common taxon $(6 \%)$. Pollen of both GMF $(2 \%)$ and LMF $(<1 \%)$ is rare, the most common taxa being Melastomataceae and Alchornea. CA pollen dominates $(88 \%)$; the most common taxa are Poaceae $(40 \%)$, Asteraceae (20\%), Eryngium type (9\%), Cyperaceae (5\%) and Baccharis type (4\%). Monolete spores (psilate type) are abundant (25\%). Zone PR-I-Ia has the highest average pollen influx in the whole core ( 9940 pollen grains $/ \mathrm{cm}^{2}$ per yr). Both small and large carbonised particles are common.

Zone PR-I-Ib (I I 6-86 cm; I0,7 I0-8990 cal. yr BP; I5 samples). Pollen of the AMF is as well represented as before (10\%). Within the UMF, Buddleia type is rarer (2\%) and Symplocos more abundant $(0-13 \%)$. GMF and LMF pollen as rare as before. CA pollen dominates $(89 \%)$ without severe changes in the pollen assemblages. Monolete spores (psilate type) decrease to 3\%. Gelasinospora spores are more common (but still $<1 \%$ ). Small carbonised 
Table 5. Rare types (maximum abundance $<1 \%$ ) in the PR-I core. Number of rare taxa present in each recognised pollen zone: total, CA taxa, AMF taxa, others (Alnus and spores).

\begin{tabular}{lllll}
\hline Pollen zone & \multicolumn{4}{l}{ Number of rare types } \\
\cline { 2 - 5 } & Total & AMF & CA & Others \\
\hline PR-I-IIlb & 20 & II & 8 & I \\
PR-I-IIla & 18 & 10 & 3 & 5 \\
PR-I-IIb & 17 & 9 & 4 & 4 \\
PR-I-Ila & 14 & 6 & 5 & 3 \\
PR-I-Ib & 17 & 7 & 6 & 4 \\
PR-I-la & II & 4 & 6 & 1 \\
(in the entire core) & 42 & 22 & 13 & 7 \\
\hline
\end{tabular}

particles are as frequent as in the previous zone, large particles more frequent than before.

Zone PR-IIla (86-50 cm; 8990-5/90 cal. yr BP; I8 samples). Pollen of the AMF group increases significantly (40\%); Symplo$\cos (34 \%)$ is the most abundant taxon. CA pollen dominates $(58 \%)$, but is less abundant than before; Poaceae (26\%), Asteraceae $(16 \%)$, Baccharis type $(6 \%)$, Cyperaceae $(5 \%)$ are the most frequent taxa. Eryngium type $(<1 \%)$ is rare. The abundance of the Pteridophyta group gradually decreases throughout the zone. Both small and large carbonised particles are rarer.

Zone PR-IIlb (50-26 cm; 5190-2670 cal. yr BP; I2 samples). Pollen of the AMF is more abundant (45\%), mostly due to Symplocos $(40 \%)$. Both GMF and LMF pollen is more common $(2 \%$ each). The further decrease of CA pollen is evident in most of the principal taxa: Poaceae (23\%), Cyperaceae (3\%) and Baccharis type (2\%); pollen of Asteraceae is also slightly less frequent but still rounds up to $16 \%$. Small carbonised particles are rarer than in the previous zone and large particles only appear at one sample.

Zone PR-IIIla (26-I2 cm; 2670-I2I0 cal. yr BP; 7 samples). Pollen of AMF taxa decreases (30\%). Symplocos is less frequent $(13 \%)$ while some rarer taxa are more abundant. Luehea $(9 \%)$, a GMF taxon, is the fourth most frequent pollen type. LMF pollen is slightly more common (still around $2 \%$ ). CA pollen increases $(67 \%)$. The most common taxa are Poaceae (37\%), Asteraceae (5-38\%), Valeriana (2-9\%) and Cyperaceae (3\%). The Pteridophyta group is more abundant $(4 \%)$. Gelasinospora spores reach their maximum values $(1 \%)$. Small and particularly large carbonised particles are more common.

Zone PR-IIIIb (I2-0 cm; I2I0 to -48 cal. yr BP; 6 samples). Within the AMF group, the UMF is the most frequent subgroup (8\%), followed by the LMF (4\%) and the GMF (3\%). CA pollen dominates $(84 \%)$. The most common taxa are Poaceae $(26 \%)$, Baccharis type (3-40\%), Asteraceae (12\%), Cyperaceae (12\%), Plantago australis type (5\%) and Croton type (2\%). This zone is characterized by abrubt changes in the pollen assemblages (e.g. Baccharis type and Plantago australis type); Croton type and Caryophyllaceae show maxima of $10 \%$ and $5 \%$, respectively, although they are not particularly common. This zone is the richest in rare types (Table 5). Small carbonised particles are rare and large particles are completely absent.

\section{Interpretation and discussion}

Early Holocene (I I,4 I 0-8990 cal. yr BP; zones PR-IIa and PR-I-Ib)

Pollen data indicate that the upper region of the Serra do Caparaó was dominated by campos de altitude, as also documented by other palaeocological records from SE Brazil (summarized in Behling, 2002). The dominance of the grassland vegetation indicates a cool climate and the abundance of Eryngium (found growing on wet soils in Serra do Caparaó) and ferns in the beginning of this period suggest humid conditions. The low abundances of pollen of Atlantic montane forest taxa in our core suggest that the forest only occurred at elevations far below our core site, with Buddleia (shrubs, small trees) possibly forming a transition 'dwarf forest' between campos de altitude and the 'true' Atlantic montane forest (see Marchant et al., 2002). This may have been due to temperature constraints, and/or relatively frequent fires, which are indicated by the high concentrations of charcoal remains. An increase of fire in this period is also reported by Power et al. (2008).

Toward the end of this period (after 10,700 cal. yr BP, pollen zone PR-I-Ib), the absence of ferns and the almost disappearing of Buddleia indicate the onset of drier conditions. Campos de altitude expanded, possibly pushing the treeline to an even lower altitude. This drier period is comparable with that found at Morro de Itapeva, Serra da Bocaina and in the Serra dos Órgãos (Behling, 1997; Behling and Safford, 2010; Behling et al., 2007) in the beginning of the Holocene.

\section{Mid-Holocene (8990-2670 cal. yr BP; zones PR-I-Ila and PR-I-IIb)}

Within the campos de altitude, the shrub genus Baccharis is the only taxon to significantly increase its abundance. Similarly, Symplocos (a UMF taxon which typically occurs in moist montane forests (Stahl, 1995)) is common in this period. The species found today in Serra do Caparaó are Symplocos densiflora and $S$. itatiaiae, both small trees or shrubs which mostly grow on rocky soils in areas of high humidity. They occur mainly in open forest in frequently burned areas but may be found in the dense forest as well. Such a strong presence of Symplocos might be a signal of mostly local importance but, together with the increase in the abundance of Baccharis, it suggests the development of a low woody layer in the vegetation resulting from an increase of humidity. This is also supported by the slight increases of GMF and LMF taxa which point to a modest forest expansion in the lowlands.

The decrease in fire frequency after $9000 \mathrm{cal}$. yr BP mentioned by Power et al. (2008) is also seen in our data through the lower influx of charcoal remains.

The changes in the vegetation, coupled with less frequent fires indicate an increase in humidity, agreeing with the results of Behling (2002) and Garcia et al. (2004), who document a broad-scale change to wetter conditions across S and SE Brazil. The increase in humidity mentioned by Araújo et al. (2005), Ledru et al. (1996) and Salgado-Laboriau et al. (1998) from 7000 to 3000 cal. yr BP onwards (exact onsets and durations varying with each study site) is also seen in our results around $5200 \mathrm{cal}$. yr BP (zone PR-I-IIb), after which time the AMF taxa and tree ferns are more strongly present in the vegetation while the abundance of CA taxa further decreases. The drier phase these authors mention to have preceeded the increase in humidity is nonetheless missing in our data.

Between 9000 and 2700 cal. yr BP, the landscape in Serra do Caparaó was thus still dominated by campos de altitude but at the core site we would probably have found a somewhat open forest with Baccharis (until 5200 cal. yr BP) and mainly Symplocos forming a shrub layer above the grassland elements. The Atlantic forest was most lithely expanding towards higher elevations but still did not reach the core site.

Late Holocene (2670 to -48 cal. yr BP (i.e. 7 I 7 BC to AD 1998); zone PR-I-IIla and PR-I-IIIb)

The shrub layer receded, leaving behind a campo de altitude dominated by Asteraceae and Poaceae. In zone PR-I-IIIa, 
Gelasinospora and carbonised particles suggest a slight increase in fire frequency. This is however reversed in PR-I-IIIb, where increases in the abundance of Cyperaceae, ferns and the shrub genera Baccharis and Croton suggest wetter climates and less frequent fire. Luehea is an important GMF taxon at the beginning of this period which includes both pioneer (Backes and Irgang, 2004; Marchant et al., 2002) and riparian species (Backes and Irgang, 2004), and its proliferation would indicate moister climatic conditions and forest expansion.

In summary, although campos de altitude dominated the landscape throughout the late Holocene, pollen abundances from our core document a progressively wetter climate, corroborating Behling's (2002) broad-scale synthesis of S and SE Brazilian paleoclimates. The maintenance of a grassland vegetation and the relatively weak presence of Atlantic montane forest taxa in the vicinity of the core site is therefore not in accordance with what we would expect given the apparently favorable conditions for a forest expansion. The expansion and current dominance of campos de altitude since $1200 \mathrm{cal}$. yr BP thus seems to be linked with human activities.

Fires have occurred throughout the Holocene, but were more frequent in the beginning of the record. As suggested by our results and reported for S Brazil (Behling et al., 2009), Morro de Itapeva (Behling, 1997), Serra da Bocaina (Behling et al., 2007) and Serra dos Órgãos (Behling and Safford, 2010), fires seem to have been more frequent before the arrival of Europeans. Thus, the current extent of campos de altitude in the Serra do Caparaó, though probably much smaller than during the early Holocene (11,400 to 9000 cal. yr BP), has almost certainly been anthropogenically increased, most likely through grazing and deforestation activities.

In the Serra do Caparaó, the latest Holocene is thus characterized by an interesting tension between forest and campos de altitude vegetation. Although the palynological evidence is for an expansion of campos de altitude, various lines of evidence (namely the increased abundances of GMF, LMF and shrub taxa within CA, as well as an increase in the diversity of rare AMF taxa) suggest that there was, and continues to be a natural tendency for the expansion of the forest in the study area. SalgadoLaboriau et al. (1998), for instance, mentions 'no record of climatic changes' and only 'small fluctuations in precipitation [...] for some areas' since 4600 cal. yr BP. In the Serra dos Órgãos (Behling and Safford, 2010), at similar altitudes to our study site and about $350 \mathrm{~km}$ to the SSW, AMF taxa are generally better represented in the pollen flora than in the Serra do Caparaó. At Morro do Itapeva (1850 m; Behling, 1997), in the southern Serra da Mantiqueira c. $500 \mathrm{~km} \mathrm{SW}$ of the Serra do Caparaó, the late Holocene is characterized by increasing humidity/precipitation and possibly temperature, accompanied by a notable expansion of montane forest. Behling (2002) synthesized 14 pollen records from S and SE Brazil and documented late-Holocene forest expansion into grasslands across the region. Given these regional patterns, montane forest taxa are surprisingly rare in the PR-I core during the Late Holocene, while at the same time, pollen abundances of a number of taxa associated with ecotonal conditions (e.g. Baccharis, Croton) and disturbed conditions (e.g. Plantago australis, Caryophyllaceae) become more frequent in the Serra do Caparaó. The relatively high diversity of rare CA taxa in zone PRI-IIIb, which contradicts the decreasing trend of the entire core could possibly be another consequence of this environmental instability.

The patterns we see in the PR-I core support the conclusion of Safford (1999a) as modern treeline (c. 1800-2200 m) elevations in SE Brazil are 'extraordinarily low for their latitude'. Pádua and Coimbra Filho (1979) and Safford (1999c) noted that grazing and anthropogenic fire were significant conservation threats in the Serra do Caparaó. Both of these disturbances favor grassland vegetation over woody species, and disturbance-tolerant rhizomatous grasses over bunchgrasses. It is clear that grass- and bamboo-dominated campos de altitude have persisted in the Serra do Caparaó since at least the Late Pleistocene, and fire is an inevitable companion of tropical highland grasslands (Ellenberg, 1979; Miehe and Miehe, 1994; Safford, 2001). However, the low influxes of charcoal remains since $1200 \mathrm{cal}$. yr BP seem to exclude fire as the main reason for this. Instead, the Serra do Caparáo lies at high altitude but not especially far from the coast $(c .130 \mathrm{~km})$ and does not rise as abruptly above its surroundings as many of the other ranges in SE Brazil. Access to its highest elevations is thus easier than in, for example, the Serra dos Órgãos or the Serra do Itatiaia. This ease of access has led to more obvious vestiges of human influence on the landscape in the Serra do Caparaó than in the latter two sites. Moreover, Euroamerican settlement of coastal Espírito Santo began in the mid-16th century and after gold was found in SE Minas Gerais at the end of the 17th century, a land rush ensued, many municipalities were founded, and exploitation of forest and mineral resources increased; grazing, charcoal exploitation, and coffee plantations followed (Dean, 1995; Gustavo et al., 2004). Facing our data, the history of Serra do Caparaó and the fact that current climates could support forest cover at higher elevations than the current treeline, it seems clear that even if fire has not been the main constraint for the forest expansion, other anthropogenic activities - e.g. grazing and logging - have most likely been the limiting factors. This might be the reason why the lower Caparaó campos de altitude seem to be a result of anthropogenic burning in what was originally montane forest (Safford, 2007).

In what concerns conservation of the natural vegetation in Serra do Caparaó, forest and shrubland expansion would in the short run help to reduce erosion and stream sedimentation, benefiting populations of many wildlife and plant species and restoring a more natural and sustainable balance to ecological patterns and processes in the National Park; in the long run, also global warming will probably intensify the upward movement of the Atlantic Forest (Behling and Safford, 2010). Nonetheless, reduction in grazing and the frequency of human-caused fire would also likely reduce the area of the current campos vegetation. Because there are so many rare and endemic species in the campos de altitude, we would recommend that naturally ignited fires be allowed to burn whenever conditions permit, in order to maintain the campos de altitude habitat in case of actual forest expansion.

\section{Conclusions}

Palynological data from the PR-I core suggest a general increase in temperature and humidity since $9000 \mathrm{cal}$. yr BP in the Serra do Caparaó, agreeing with the regional trends summarized for the vegetation and fire history in Behling (2002) and Power et al. (2008), respectively. Throughout the Holocene, campos de altitude have been the dominant vegetation at higher elevations in the Serra do Caparaó. The area dominated by herbaceous vegetation decreased between 9000 and $2700 \mathrm{cal}$. yr BP, when the shrub component - mainly because of Symplocos - increased in importance. After 2700 cal. yr BP the natural succession first seems to have achieved a new succession level towards the forest expansion: The arboreal taxon Luehea appears as an important element of the vegetation, ferns became more abundant and the diversity of rare Atlantic montane forest taxa increased. However, after 1200 cal. yr BP, the dominance shifts again to campos de altitude taxa (Poaceae, Asteraceae, Cyperaceae) with some signals of environmental instability.

Evidence from this and comparisons with other studies suggest that forest vegetation should be more important in Serra do Caparao than it currently is, thus the expansion of campos de altitude in the late Holocene (after 1200 cal. yr BP) seems to be anthropogenic influenced, most likely through grazing and deforestation activities. 


\section{Acknowledgments}

AMS radiocarbon dating was carried out at Lawrence Livermore National Laboratory (USA), with the help and advice of John Southon and Brian Frantz. For their help and support while carrying out this study, thanks go to students and co-workers of the Palynology Department of the Georg-August-Universität Göttingen, especially Martin Zweigert, Vivian Jeske-Pieruschka, Lisa Schüler and Petra Lembcke. We thank Lucio Leoni of the Herbário Guido Pabst (Carangola, Minas Gerais) for logistical support and help in the field. Finally, we thank two anonymous reviewers for providing constructive criticism.

\section{Funding}

We gratefully acknowledge the permission to do research in Serra do Caparaó, granted to H Safford under IBAMA license number 62/97 and CNPq Portaria 368/97.

\section{References}

Aguiar AP, Chiarello AG, Mendes SL et al. (2003) The central and Serra do Mar corridors in the Brazilian Atlantic forest. In: Galindo-Leal C and Câmara IG (eds) The Atlantic Forest of South America, Biodiversity Status, Threats, and Outlook. Center for Applied Biodiversity Science at Conservation International, pp. 118-132.

Alexopolous CJ, Mins CW and Blackwel M (1996) Introductory Mycology, 4th Edition. John Wiley \& Sons.

Araújo AGM, Neves WA, Piló LB et al. (2005) Holocene dryness and human occupation in Brazil during the 'Archaic Gap'. Quaternary Research 64: 298-307.

Backes P and Irgang B (2004) Mata alântica, as árvores e a paisagem. Editora Paisagem do Sul.

Behling H (1992) Untersuchungen zur spätpleistozänen und holozänen Vegetations- und Klimageschichte der tropischen Küstenwälder und der Araukarienwälder in Santa Catarina (Südbrasilien). Dissertationes Botanicæ, Band 206.

Behling H (1997) Late Quaternary vegetation, climate and fire history from the tropical mountain region of Morro de Itapeva, SE Brazil. Palaeogeography, Palaeoclimatology, Palaeoecology 129: 407-422.

Behling H (2000) Araukarienwälder Südbrasiliens in Spätquartär. Natur und Museum 130: 155-161.

Behling H (2002) South and southeast Brazilian grasslands during Late Quaternary times: A synthesis. Palaeogeography, Palaeoclimatology, Palaeoecology 177: 19-27.

Behling H and Safford HD (2010) Late-glacial and Holocene vegetation, climate and fire dynamics in the Serra dos Órgãos, Rio de Janeiro State, SE Brazil. Global Change Biology 16: 1661-1671.

Behling H, Dupont L, Safford HD et al. (2007) Late Quaternary vegetation and climate dynamics in the Serra da Bocaina, southeastern Brazil. Quaternary International 161: 22-31.

Behling H, Jeske-Pieruschka V, Schüler L et al. (2009) Dinâmica dos campos no sul do Brasil durante o Quaternário tardio. In: Pillar VP, Müller SC, Castilhos ZMS et al. (eds) Campos sulinos - Conservação e uso sustentável da biodiversidade. Ministério do Meio Ambiente, Secreteria de Biodiversidade e Florestas, Departamento de Conservação da Biodiversidade, pp. 13-25.

Brade AC (1942) Excursão à Serra do Caparaó. Revista do Serviço Florestal - Rodriguésia 15, pp. 87-92.

Bush MB and Weng MB (2006) Introducing a new (freeware) tool for palynology. Journal of Biogeography 34: 377-380.

Câmara IG (2003) Brief history of conservation in the Atlantic forest. In: Galindo-Leal C and Câmara IG (eds) The Atlantic Forest of South America, Biodiversity Status, Threats, and Outlook. Center for Applied Biodiversity Science at Conservation International, pp. 31-42.

Dean W (1995) With Broadax and Firebrand. The Destruction of the Brazilian Atlantic Forest. Berkeley CA: University of California Press.

Ellenberg H (1979) Man's influence on tropical mountain ecosystems in South America. Journal of Ecology 67: 401-416.

Fægri K and Iversen J (1989) Textbook of Pollen Analysis, 4th Edition. John Wiley \& Sons.

Galindo-Leal C and Câmara IG (2003) The Atlantic Forest of South America, Biodiversity Status, Threats, and Outlook. Center for Applied Biodiversity Science at Conservation International.
Garcia MJ, de Oliveira PE, de Siqueira E et al. (2004) A Holocene vegetational and climatic record of the Atlantic rainforest belt of coastal State of São Paulo, SE Brazil. Review of Palaeobotany and Palynology 131: 181-199.

Grimm EC (1987) CONISS: A Fortran 77 program for stratigraphically constrained cluster analysis by the method of the incremental sum of squares. Pergamon Journal 13: 13-35.

Gustavo ABF, Rylands A, Paglia A et al. (2004) Atlantic Forest. In: Mittermeier RA (ed.) Hotspots Revisited. Cemex, pp. 84-88.

Hueck K (1966) Die Wälder Südamerikas. Fischer Verlag.

Jensen C and Elverland E (2002) Vegetasjonshistorie og bosetningsfaser på Melkøya og Meland gjennom de siste ca. 10.000 år. Meløyaprosjektet Kulturhistoriske Registreringer og Utgravninger 2001 og 2002 Appendix. http://www.ub.uit.no/munin/bitstream/10037/2437/2/appendiks.pdf (18th May 2010).

Ledru M-P (1993) Late Quaternary environmental and climatic changes in central Brazil. Quaternary Research 39: 90-98.

Ledru M-P, Braga PIS, Soubiès F et al. (1996) The last 50,000 years in the Neotropics (Southern Brazil): Evolution of vegetation and climate. Palaeogeography, Palaeoclimatology, Palaeoecology 123: 239-257.

Leoni, LS (1997) Catálogo preliminar das fanerógamas ocorrentes no Parque Nacional do Caparaó - MG. Pabstia VIII(2): 1-28.

Marchant R, Almeida L, Behling H et al. (2002) Distribution and ecology of parent taxa of pollen lodged within the Latin American Pollen Database. Review of Palaeobotany and Palynology 121: 1-75.

Martinelli G (1996) Campos de altitude. Editora Index.

Miehe G and Miehe S (1994) Zur oberen Waldgrenze in tropischen Gebirgen. Phytocoenologia 24: 53-110.

Nimer E (1979) Climatologia do Brasil. Série Recursos Naturais e Meio Ambiente, no. 4.

Pádua MTJ and Coimbra Filho AF (1979) Os parques nacionais do Brasil (coleção 'A Natureza na Iberoamérica'). Instituto de Cooperação Iberoamericana \& Instituto de la Caza Fotográfica y Ciencias de la Naturaleza (INCAFO).

Por FD (1992) Sooretama: The Atlantic Rainforest of Brazil. The Hague: SPB Academic Publishing.

Power MJ, Marlon J, Ortiz N et al. (2008) Change in fire regimes since Last Glacial Maximum: An assessment based on global synthesis and analysis of charcoal data. Climate Dynamics 30: 887-907.

Romariz DA (1972). A vegetação. In: A. Azevedo (ed.) Brasil: a terra e o homen. São Paulo: Editora Universidade de São Paulo, pp. 521-562.

Ruschi A (1950) Fitogeografia do Estado do Espírito Santo. Considerações gerais sobre a distribuição da flora no Estado do ES. Boletim do Museu de Biologia Mello Leitão, Serie Botânica 1.

Safford HD (1999a) Brazilian páramos I. An introduction to the physical environment and vegetation of the campos de altitude. Journal of Biogeography 26: 693-712.

Safford HD (1999b) Brazilian páramos II. Macro- and mesoclimate of the campos de altitude and affinities with high mountain climates of the tropical Andes and Costa Rica. Journal of Biogeography 26: 713-737.

Safford HD (1999c) Notas sobre a ecologia e a preservação de Nothochilus coccineus Radlkofer (Scrophulariaceae), espécie endêmica do Maciço do Caparaó, ES/MG. Acta Botânica Brasileira 13: 175-185.

Safford HD (2001) Brazilian páramos III. Patterns and rates of postfire regeneration in the campos de altitude. Biotropica 33: 282-302.

Safford HD (2007) Brazilian páramos IV. Phytogeography of the campos de altitude. Journal of Biogeography 34: 1701-1722.

Safford HD and Martinelli G (2000) Southeast Brazil. In: Barthlott W and Porembski S (eds) Inselbergs: Biotic Diversity of Isolated Rock Outcrops in Tropical and Temperate Regions. Ecological Studies No. 146. Berlin: Springer-Verlag, pp. 339-389.

Salgado-Laboriau ML, Barberi M, Ferraz-Vicentini KR et al. (1998) A dry climatic event during the late Quaternary of tropical Brazil. Palaeogeography, Palaeoclimatology, Palaeoecology 99: 115-129.

Schüler L and Behling H (2011a) Poaceae pollen grain size as a tool to distinguish past grasslands in South America-A new methodological approach. Vegetation History and Archaeobotany 20: 83-96.

Schüler L and Behling H (2011b) Characteristics of Poaceae pollen as a tool to assess palaeoecological grassland dynamics in South America. Vegetation History and Archaeobotany 20: 97-108.

Sitte P, Ziegler H, Ehrendorfer F et al. (1998) Strasburger Lehrbuch der Botanik, 34. Auflage. Gustav Fischer Verlag.

Stahl B (1995) Diversity and distribution of Andean Symplocaceae. In: Churchill SP, Balslev H, Forero E et al. (eds) Biodiversity and Conservation of Neotropical Montane Forests. Bronx: New York Botanical Garden, pp. 397-405. 